\title{
Pengaruh Lidah Buaya (Aloe vera L.) pada Paru-Paru Tikus yang Diinduksi Asap Rokok
}

\author{
Nur Atik, ${ }^{1}$ Erda Avriyanti, ${ }^{2}$ Januarsih Iwan A. R., ${ }^{1}$ Agnes Rengga Indrati, ${ }^{3}$ Rachmat Gunadi W. ${ }^{2}$ \\ ${ }^{1}$ Departemen Biologi Sel, ${ }^{2}$ Divisi Reumatologi Departemen Ilmu Penyakit Dalam, \\ ${ }^{3}$ Departemen Patologi Klinik Fakultas Kedokteran Universitas Padjadjaran \\ Rumah Sakit Dr. Hasan Sadikin Bandung
}

\begin{abstract}
Abstrak
Kejadian merokok merupakan salah satu masalah kesehatan dunia karena dapat meningkatkan angka kejadian penyakit paru obstruktif kronik (PPOK). Lidah buaya (Aloe vera L.) merupakan tanaman fungsional sebagai antiinflamasi, imunomodulator, dan kandungan $\beta$-sitosterol. Penelitian bertujuan untuk mengetahui pengaruh lidah buaya pada pencegahan kejadian apoptosis, peningkatan jumlah serta penurunan fungsi fagositosis makrofag pada paru-paru tikus (Rattus norvegicus) yang diinduksi dengan asap rokok. Penelitian dilakukan periode Januari 2009-Januari 2010 bertempat di Departemen Biologi Sel, Patologi Klinik, Patologi Anatomi, dan Unit Penelitian Kesehatan Fakultas Kedokteran Universitas Padjadjaran. Penelitian laboratorik eksperimental menggunakan tikus sebagai subjek, dibagi menjadi 3 kelompok (kontrol, rokok, dan rokok ditambah lidah buaya) masing-masing sebanyak 8 ekor dan lama perlakuan selama 42 hari. Data diperoleh melalui pengamatan jumlah sel makrofag dan aktivitas fagositosisnya, serta ekspresi Bcl2 sel epitel alveolus kemudian dianalisis statistik menggunakan uji Mann-Whitney. Hasil penelitian menunjukkan jumlah makrofag rata-rata pada kelompok rokok $(495,88 \pm 104,09)$ lebih banyak dibandingkan dengan kelompok rokok ditambah lidah buaya $(295,63 \pm 176,79)(p<0,05)$ namun hasil uji fagositosis makrofag menunjukkan hasil sebaliknya. Kelompok rokok ditambah lidah buaya memiliki persentase yang lebih tinggi $(11,67 \pm 12,84)$ dibandingkan dengan kelompok rokok $(3,77 \pm 1,39)$. Ekspresi Bcl2 pada sel alveolus paru-paru tikus kelompok rokok ditambah lidah buaya lebih tinggi dibandingkan dengan kelompok kontrol dan rokok $(\mathrm{p}<0,05)$. Simpulan, gel lidah buaya meningkatkan jumlah dan aktivitas sel makrofag serta ekspresi Bcl2 pada paru-paru tikus yang telah diinduksi asap rokok. [MKB. 2012;44(3):159-64].
\end{abstract}

Kata kunci: Bcl2, lidah buaya (Aloe vera L.), makrofag, rokok

\section{The Effect of Aloe vera $L$. in Rat Lungs After Cigarette Smoke Induction}

\begin{abstract}
The incident of smoking is one of the world's health problems, as smoking increases the incidence of chronic obstructive pulmonary disease (COPD). Aloe vera L has anti-inflammatory, immunomodulator, and $\beta$-sitosterol properties. A research was conducted to observe its effects in preventing the cell apoptotic events as well as the increasing numbers of macrophages and the decreasing phagocytotic function of macrophages in rat's lung (Rattus norvegicus) that has been induced by cigarettes smoke. The study was conducted in January 2009-January 2010, located in Department of Cell Biology, Clinical Pathology, Anatomy Pathology and Health Research Unit of Faculty of Medicine University of Padjadjaran.This experimental study was conducted on rats which were divided into 3 groups each consisted 8 rats for 42 days in treatments. The data were collected from number of macrophages and its activity and also alveoli epithelial cell $\mathrm{Bcl} 2$ expression observation, than statistical analytic was performed using Mann-Whitney test. Result showed the significant difference $(p<0.05)$ in number of macrophages, cigarette smoke group had a higher number $(495.88 \pm 104.09)$ than cigarette smoke plus aloe group (295.63 \pm 176.79$)$ but it showed the opposite for the phagocytotic function of macrophages. The cigarette smoke plus aloe group had higher percentage (11.67 \pm 12.84$)$ than cigarette smoke group (3.77 \pm 1.39$)$. Observation of Bcl2 expression in rat's lungs alveoli cell showed that the group exposed to cigarettes and Aloe vera were more expressed compared with cigarette exposed group $(\mathrm{p}<0.05)$. This study proved that Aloe vera gel increases the number and cell activity of macrophages in addition to the $\mathrm{Bcl} 2$ expression in rat lungs which have been induced by cigarette smoke. [MKB. 2012;44(3):159-64].
\end{abstract}

Key words: Aloe vera L., Bcl2, cigarette, macrophages

Korespondensi: Nur Atik, dr., M.Kes, Departemen Biologi Sel Fakultas Kedokteran Universitas Padjadjaran Bandung, Jalan Raya Bandung Sumedang km 21, telepon (022) 7796373 


\section{Pendahuluan}

Pada saat ini kejadian merokok merupakan salah satu masalah kesehatan dunia, karena merokok dapat meningkatkan angka kejadian kanker paru dan penyakit paru obstruktif kronik (PPOK). ${ }^{1,2}$ Kandungan tinggi radikal bebas serta zat lain pada rokok yang dapat meningkatkan produksi radikal bebas dalam tubuh dapat memengaruhi struktur traktus respiratorius. ${ }^{1,3}$

Penyakit paru obstruktif kronik merupakan penyebab kematian terbanyak ke-5 di dunia (menurut World Health Organization/WHO tahun 2002 sekitar 2.500.000 penderita PPOK meninggal setiap tahun).,5 Untuk Indonesia, sejauh ini belum ada data nasional mengenai prevalensi PPOK, namun penderita penyakit ini menunjukkan kecenderungan peningkatan setiap tahunnya. ${ }^{4,5}$

Pada penderita PPOK, sel makrofag paru-paru akan meningkat pada saat toksin, materi organik dan inorganik (misalnya asap rokok) terinhalasi sebagai respons awal tubuh. Pemeriksaan paruparu pada perokok usia muda menunjukkan akumulasi makrofag pada daerah bronkus dan bronkiolus.

Makrofag yang diisolasi dari cairan broncho alveolar limphoid tissue (BALT) paru-paru perokok dan penderita PPOK meningkat beberapa kali normal, namun ukuran lebih kecil atau kemungkinan imatur dibandingkan dengan makrofag dari paru-paru normal. ${ }^{6}$

Terdapat peningkatan apoptosis sel epitel alveoli dan endotel paru-paru penderita PPOK. Pada waktu terjadi ketidakseimbangan antara pertumbuhan dan kematian sel, maka akan terjadi destruksi jaringan paru yang pada akhirnya terjadi emfisema. Data perlakuan secara in vitro memperlihatkan peran $\mathrm{Bcl} 2$ terhadap penurunan apoptosis pada sel paru. ${ }^{1,7}$

Lidah buaya merupakan tumbuhan yang tidak asing lagi bagi masyarakat Indonesia. Lidah buaya dinyatakan sebagai tanaman yang fungsional karena semua bagian tanaman ini dapat dimanfaatkan. ${ }^{8}$

Manfaatnya antara lain sebagai antiinflamasi, antioksidan, antipenuaan, antikanker, dan imunomodulator yang semuanya berhubungan dengan reactive oxygen spesies (ROS) yang dikandungnya. ${ }^{9-11}$

Untuk mengetahui efek lidah buaya sebagai perlindungan paru-paru terhadap asap rokok pada tikus yang diinduksi asap rokok, maka dilakukan penelitian mengenai pengaruh lidah buaya pada pencegahan kejadian apoptosis, peningkatan jumlah, serta penurunan fungsi fagositosis makrofag pada paru-paru tikus (Rattus norvegicus) yang diinduksi asap rokok.

\section{Metode}

Penelitian ini merupakan percobaan laboratorik eksperimental menggunakan hewan coba berupa 24 ekor tikus (Rattus norvegicus) jantan galur Wistar albino usia 9-11 minggu dengan bobot rata-rata 180-220 gram yang didapat dari Institut Teknologi Bandung (ITB) dengan kriteria inklusi bobot 200-250 gram dan tikus dalam keadaan sehat, sedangkan kriteria eksklusi apabila tikus dalam keadaan sakit seperti kurang lincah atau tidak nafsu makan. Penelitian dilakukan periode Januari 2009-Januari 2010 bertempat di Departemen Biologi Sel, Patologi Klinik, Patologi Anatomi, dan Unit Penelitian Kesehatan Fakultas Kedokteran Universitas Padjadjaran.

Hewan coba dibagi menjadi tiga kelompok perlakuan yang masing-masing berjumlah 8 ekor. Tikus diberi perlakuan sesuai dengan kelompok masing-masing (Gambar 1).

Kelompok kontrol tikus hanya mendapatkan makanan dan minuman seperti biasa. Pada hari ke-42, tikus dikorbankan kemudian jaringan paru-paru diambil untuk pengisolasian makrofag dan pembuatan preparat dengan pewarnaan imunohistokimia Bcl-2.

Delapan tikus dalam kelompok asap rokok diberikan perlakuan yang sesuai dengan penelitian Arkeman, ${ }^{12}$ yaitu pemberian asap rokok 8 batang selama 30 menit per hari selama 42 hari. Pada hari ke-42, semua tikus dikorbankan, kemudian jaringan paru-paru diambil untuk isolasi makrofag dan pembuatan preparat memakai pewarnaan imunohistokimia Bcl-2.

Kelompok terakhir yaitu kelompok tikus yang mendapatkan perlakuan pemberian asap

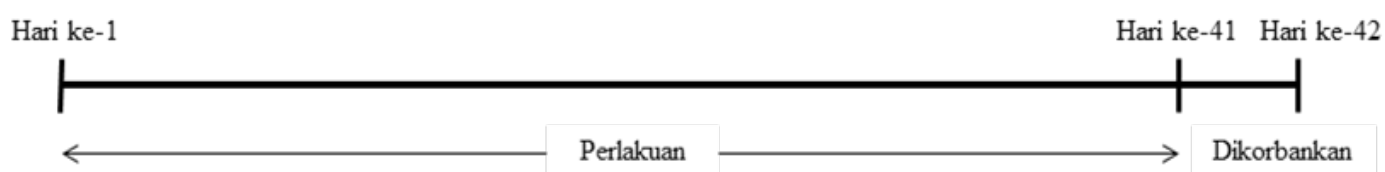

Gambar 1 Skema Percobaan

Tikus diberi perlakuan sesuai dengan kelompok masing-masing dan dikorbankan pada hari ke-42 
rokok 8 batang selama 30 menit per hari selama 42 hari ditambah pemberian jus gel lidah buaya sebanyak $1 \mathrm{~mL} /$ hari. Pada hari ke- 42 , semua tikus dikorbankan, kemudian jaringan paru-paru diambil untuk isolasi makrofag dan pembuatan sediaan preparat dengan pewarnaan imunohistokimia Bcl-2.

Pewarnaan imunohistokimia Bcl-2 untuk melihat ekspresi protein $\mathrm{Bcl}-2$ yang berpengaruh pada kejadian apoptosis. Preparat yang telah diwarnai dengan pewarnaan imunohistokimia akan dilihat di bawah mikroskop cahaya. Apabila pada preparat paru-paru tersebut terdapat banyak ekspresi Bcl-2 maka diduga terjadi penghambatan proses apoptosis dari jalur intrinsik.

Setelah paru-paru tikus dikeluarkan dari rongga dada dan diletakkan pada cawan petri, disuntikkan 2,5 $\mathrm{mL}$ media kultur jaringan ke paru-paru (pastikan terjadi perubahan warna). Ambil supernatan dan pindahkan ke dalam falcon tube $15 \mathrm{~mL}$, sentrifus $1.200 \mathrm{rpm} 4^{\circ} \mathrm{C}$ selama 10 menit kemudian hitung jumlah makrofag menggunakan hemositometer. Uji fagositosis dengan memberikan latex beads berdiameter 2-3 $\mu \mathrm{m}$ pada makrofag yang diwarnai dengan Giemsa dan dilihat di bawah mikroskop.

Uji normalitas Kolmogorov-Smirnov dipakai untuk menentukan distribusi data hasil penelitian, selanjutnya dilakukan uji homogenitas varians Levene test. Apabila hasil menunjukkan data yang tidak berdistribusi normal, maka dilakukan uji nonparametrik Mann-Whitney. Analisis tersebut dilakukan dengan menggunakan program SPSS for windows versi 13.0.

\section{Hasil}

Setelah dilakukan perlakuan terhadap hewan coba, tiap kelompok dievaluasi apakah terdapat subjek penelitian yang diduga sakit, salah satunya dengan menilai bobot masing-masing tikus. Hasil penimbangan bobot rata-rata hewan coba tiap kelompok mengalami peningkatan (Gambar 2). Subjek lalu dikorbankan, paru-paru dikeluarkan kemudian dilakukan isolasi dan uji fagositosis makrofag serta pembuatan immunohistochemistry (IHC) dengan antibodi Bcl2 (Gambar 3). Hasil masing-masing parameter selanjutnya dianalisis secara statistik.

Jumlah makrofag rata-rata pada kelompok rokok yang diberi lidah buaya $(295,63 \pm 176,79)$ lebih banyak bila dibandingkan dengan kontrol $(144,88 \pm 24,92)$, begitu pula pada kelompok rokok $(495,88 \pm 104,09)$ yang terlihat lebih banyak bila dibandingkan dengan kontrol, bahkan lebih banyak dibandingkan dengan kelompok rokok ditambah lidah buaya. Hasil uji Mann-Whitney menunjukkan perbedaan jumlah makrofag secara bermakna (Tabel 1).

Pada hasil penelitian ini, persentase aktivitas fagosit makrofag rata-rata kelompok rokok ditambah lidah buaya $(11,67 \pm 12,84)$ lebih besar bila dibandingkan dengan kontrol $(9,79 \pm 3,15)$. Hasil yang menarik yaitu pada kelompok rokok, meskipun jumlah makrofag meningkat namun ternyata efektivitas fagositosis rendah (persentase $3,77 \pm 1,39)$. Hasil tersebut kemudian dilanjutkan dengan uji Mann-Whitney. Hasil uji MannWhitney ternyata tidak menunjukkan perbedaan

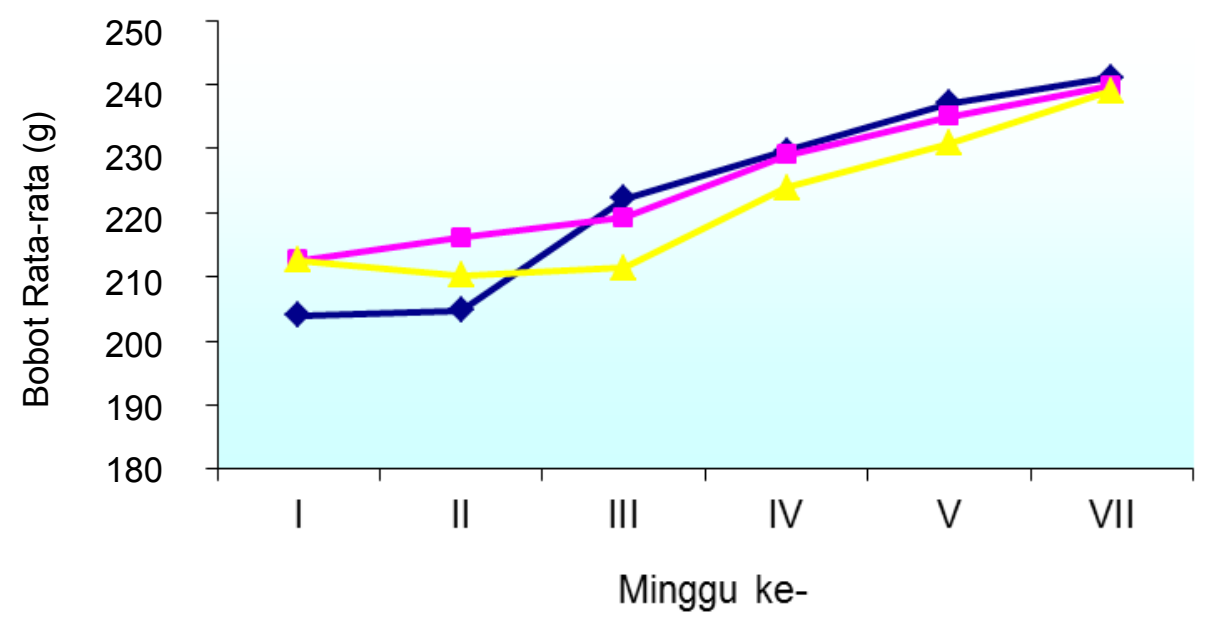

$\multimap$ Kontrol $\rightarrow$ Lidah Buaya+ Rokok $\longrightarrow$ Rokok

Gambar 2 Pertumbuhan Bobot Rata-rata Tikus pada Ketiga Kelompok 
Tabel 1 Hasil Uji Mann-Whitney berdasarkan Jumlah Makrofag

\begin{tabular}{lcl}
\hline Perbedaan & $\mathbf{p}$ & Hasil \\
\hline Kontrol vs Rokok + Lidah Buaya & 0,031 & Berbeda \\
Kontrol vs Rokok & 0,001 & Berbeda \\
Rokok + Lidah Buaya vs Rokok & 0,031 & Berbeda \\
\hline
\end{tabular}

Tabel 2 Hasil Uji Mann-Whitney berdasarkan Persentase Aktivitas Fagosit Makrofag

\begin{tabular}{lcc}
\hline Perbedaan & $\mathbf{p}$ & Hasil \\
\hline Kontrol vs Rokok + Lidah Buaya & 0,401 & Tidak berbeda \\
Kontrol vs Rokok & 0,001 & Berbeda \\
Rokok + Lidah Buaya vs Rokok & 0,372 & Tidak berbeda \\
\hline
\end{tabular}

bermakna antara kelompok rokok dan kelompok rokok ditambah lidah buaya (Tabel 2).

Ekspresi Bcl2 pada kelompok rokok sebesar $3 / 8$ untuk positif lemah dan $5 / 8$ positif sedang. Ekspresi Bcl2 pada kelompok rokok ditambah lidah buaya terdiri atas $5 / 8$ memiliki nilai positif sedang dan 3/8 terekspresi kuat. Uji MannWhitney terdapat perbedaan bermakna ekspresi Bcl2 antara kelompok rokok dan kelompok rokok + lidah buaya $(\mathrm{p}<0,05)($ Tabel 3$)$.

\section{Pembahasan}

Penelitian menunjukkan jumlah makrofag ratarata kelompok rokok lebih banyak dibandingkan dengan kelompok kontrol dan kelompok rokok ditambah lidah buaya. Asap rokok diketahui dapat meningkatkan jumlah makrofag alveolar menjadi 2-3 kali lebih banyak pada bronchialassociated lymphoid tissue (BALT) perokok. Hal ini disebabkan karena rokok terdiri atas kurang lebih 7.000 bahan kimia, ratusan di antaranya bahan beracun dan sekitar 70 substrat dapat menyebabkan kanker. ${ }^{13}$ Makrofag merupakan sel terbanyak pada paru-paru jika dilihat dari jumlah populasinya dan berfungsi sebagai pertahanan utama untuk melawan polutan melalui fungsinya sebagai sel fagositosis dan antigen presenting cell (APC). ${ }^{1,6}$

Jumlah makrofag rata-rata kelompok rokok dengan lidah buaya menunjukkan jumlah yang relatif lebih sedikit dan berbeda secara bermakna jika dibandingkan dengan kelompok rokok. Hal ini dapat dijelaskan karena kandungan gel lidah buaya yang memiliki bahan antioksidan dan antiinflamasi seperti pada kandungan sterol yang diketahui sangat berperan dalam inhibisi peradangan akut, mirip dengan kerja kortison, tetapi tanpa efek samping. Selain antiinflamasi, berbagai studi telah membuktikan bahwa lidah buaya memiliki kemampuan untuk menstimulasi makrofag. $9,11,14,15$

Walaupun didapatkan peningkatan jumlah makrofag pada kelompok tikus yang dipaparkan asap rokok bahkan jumlah tersebut lebih tinggi jika dibandingkan dengan kelompok rokok dan gel lidah buaya, namun hasil uji fungsi fagositosis makrofag menunjukkan hasil yang berkebalikan. Aktivitas fagositosis rata-rata kelompok rokok lebih rendah dibandingkan dengan kelompok kontrol dan kelompok rokok yang ditambah dengan gel lidah buaya. Hal ini sejalan dengan teori yang menyatakan terjadi penurunan fungsi makrofag pada perokok. ${ }^{1}$ Droemann dkk. ${ }^{16}$ menyatakan bahwa alveolar makrofag pada perokok mengalami penurunan ekspresi Toll-like receptor 2 (TLR2) jika dibandingkan dengan nonperokok. Dapat dikatakan pula bahwa sifat antigenisitas makrofag alveolar dapat dipengaruhi oleh sifat fagositosis sel lain, sel yang mengalami apoptosis atau nekrosis dan fragmen sel. Umur hidup makrofag alveolar pada seorang perokok juga mengalami peningkatan (normal sekitar 80 hari). ${ }^{1}$

Aktivitas makrofag rata-rata pada kelompok rokok ditambah dengan lidah buaya lebih tinggi dibandingkan kelompok rokok. Hal ini diduga karena lidah buaya memiliki kemampuan untuk menstimulasi makrofag. Ternyata polisakarida rantai panjang (B1-3 dan B1-4 glukomanan) lidah buaya mempunyai peranan langsung untuk

Tabel 3 Perbedaan Ekspresi Bcl2 antara Kelompok Perlakuan Rokok dan Rokok + Lidah Buaya

\begin{tabular}{|c|c|c|c|c|}
\hline \multirow{2}{*}{ Perlakukan } & \multicolumn{3}{|c|}{ Bcl2 } & \multirow[b]{2}{*}{$\mathbf{p}$} \\
\hline & Positif Lemah & Positif Sedang & Positif Kuat & \\
\hline Rokok & 3 & 5 & 0 & \multirow{2}{*}{0,018} \\
\hline Rokok + Lidah Buaya & 0 & 5 & 3 & \\
\hline
\end{tabular}




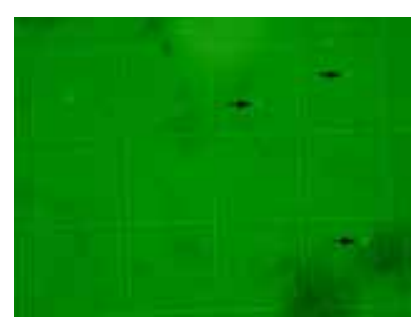

$\mathbf{a}$

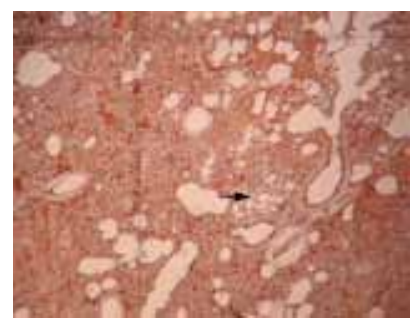

d

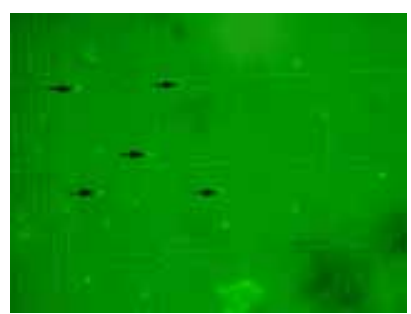

b

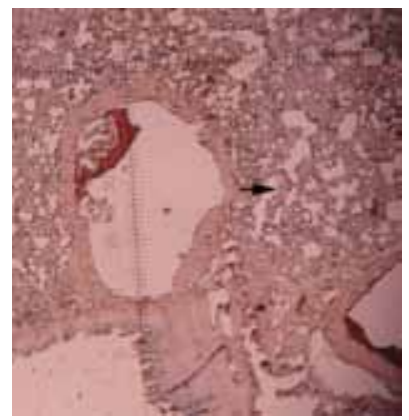

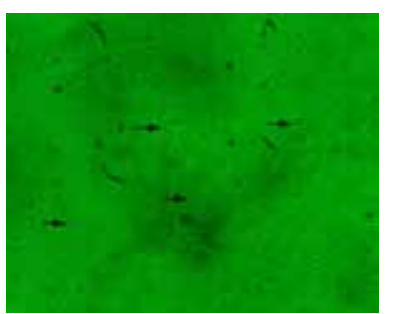

b

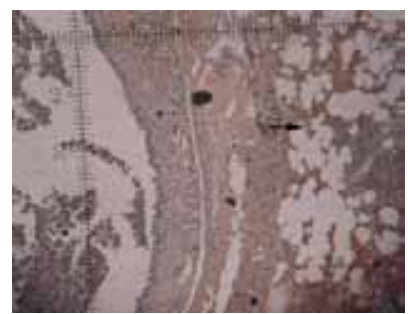

f

Gambar 3 Hasil Penelitian. (a) Makrofag pada Kelompok Kontrol (Pembesaran 100x). (b) Makrofag pada Kelompok Rokok + Lidah Buaya (Pembesaran 100x). (c) Aktivitas Fagositosis Makrofag pada Kelompok Rokok + Lidah Buaya (Pembesaran 400x). (d) Gambaran Ekspresi Bcl2 (Positif Kuat) pada Alveolar Paru-paru Tikus Kelompok Kontrol (Imunohistokimia Bcl2, 100x). (e) Gambaran Ekspresi Bcl2 (Positif Sedang) pada Alveolar Paru-paru Tikus Kelompok Rokok + Lidah Buaya (Imunohistokimia Bcl2, 100x). (f) Gambaran Ekspresi Bcl2 (Positif Sedang) pada Alveolar Paru-paru Tikus Kelompok Rokok (Imunohistokimia Bcl2, 100x)

meningkatkan dan modulasi sistem imun, dengan meningkatkan produksi sel imun, menstimulasi dan memperbaiki aktivitas leukosit. . $^{3,9,11,14,15}$ Walaupun terdapat perbedaan aktivitas fagosit, namun setelah diuji statistik ternyata perbedaan tersebut tidak bermakna. Alasan yang mungkin untuk menjelaskan hal tersebut oleh karena jumlah sampel pada penelitian ini minim.

Hasil pengamatan terhadap ekspresi $\mathrm{Bcl} 2$ menunjukkan kelompok rokok ditambah lidah buaya lebih terekspresi dibandingkan dengan kelompok rokok $(\mathrm{p}<0,05)$. Bcl2 merupakan suatu protein atau gen yang dapat menghambat kejadian apoptosis pada sel, dalam penelitian ini yaitu sel epitel alveolus. Bcl2 menghambat kejadian apoptosis dengan cara menghambat pelepasan sitokrom $\mathrm{C}$ dari mitokondria. ${ }^{17,18}$

Liu dkk. ${ }^{19}$ dalam penelitiannya menyimpulkan bahwa terjadi apoptosis pada sel epitel alveolar dan sel endotel vaskular pulmonal pada penderita PPOK dan tikus coba yang diinduksi asap rokok. Gel lidah buaya diketahui memiliki kandungan senyawa angiogenik yang poten, yaitu $\beta$-sitosterol yang dapat menginduksi formasi pembuluh darah baru melalui peningkatan vascular endothelial growth factor (VEGF), sehingga dengan demikian diharapkan angka kejadian apoptosis menurun., ${ }^{9,11}$

Pemilihan parameter Bcl2 untuk memprediksi kemungkinan kejadian apoptosis pada sel boleh dikatakan sangat lemah, karena jalur-jalur pada kematian apoptosis cukup banyak. Kaspase-9 berperanan pada jalur instrinsik, kaspase- 8 pada jalur ekstrinsik, sedangkan kaspase-3 sebagai protein eksekutor yang terlibat dalam proses apoptosis atau bahkan protein poly (ADP-ribose) polymerase (PARP) yang merupakan tanda terjadinya fragmentasi deoxyribonucleic acid (DNA) pada sel yang mengalami apoptosis dapat kita pakai sebagai pertanda apoptosis yang lebih bermakna dibandingkan dengan $\mathrm{Bcl} 2$ sendiri. ${ }^{17,18}$ Pada penelitian ini dapat dikatakan gel lidah buaya meningkatkan ekspresi protein Bcl 2 pada sel epitel paru-paru yang telah diinduksi asap rokok. Simpulan, gel lidah buaya meningkatkan jumlah serta aktivitas sel makrofag ekspresi Bcl2 pada paru-paru tikus yang diinduksi asap rokok.

\section{Ucapan Terima Kasih}

Terima kasih kepada Universitas Padjadjaran 
karena penelitian ini dibiayai oleh dana DIPA Universitas Padjadjaran sesuai dengan Surat Keputusan Rektor Unpad No.1159/H6.1/Kep/ HK/2009 tanggal 14 April 2009.

\section{Daftar Pustaka}

1. Domagala-Kulawik J. Effects of cigarette smoke on the lung and systemic immunity. J Physiol Pharmacol. 2008;59(Suppl 6):1934.

2. Hsu CL, Wu YL, Tang GJ, Lee TS, Kou YR. Ginkgo biloba extract confers protection from cigarette smoke extract-induced apoptosis in human lung endothelial cell: Role of heme oxygenase-1. Pulm Pharmacol Ther. 2009; 22(4):286-96.

3. $\mathrm{Hu} \mathrm{Y,} \mathrm{Xu} \mathrm{J,} \mathrm{Hu} \mathrm{Q.} \mathrm{Evaluation} \mathrm{of} \mathrm{antioxidant}$ potential of aloe vera (Aloe barbadensis miller) extract. J Agric Food Chem. 2003;51(26):7788-91.

4. Lopez AD, Murray CC. The global burden of disease, 1990-2020. Nat Med. 1998;4(11):1241-3.

5. American Lung Association. Epidemiology and statistics unit, research and program services [serial online] 2005 May [diunduh 12 Juni 2008]. Tersedia dari: http://www. lungusa.org/atf/cf/\%7B7A8D42C2-FCCA4604-8ADE-7F5D5E762256\%7D/COPD1.

6. TetleyTD. Macrophages and the pathogenesis of COPD. Chest. 2002;121(5 Suppl):156-9S.

7. Demedts IK, Demoor T, Bracke KR, Joos GF, Brusselle GG. Role of apoptosis in the pathogenesis of COPD and pulmonary emphysema. Respir Res. 2006;7:53.

8. Furnawathi, I. Khasiat dan manfaat lidah buaya si tanaman ajaib. Cetakan ke-7. Jakarta: Agro Media Pustaka; 2006.

9. Moon EJ, Lee YM, Lee OH, Lee MJ, Lee SK, Chung MH, dkk. A novel angiogenic factor derived from Aloe vera gel: beta-sitosterol, a plant sterol. Angiogenesis. 1999;3(2):11723.

10. Zhang XF, Wang HM, Song YL, Nie LH, Wang LF, Liu B, dkk. Isolation, structure elucidation, antioxidative and immunomodulatory properties of two novel dihydrocoumarins from Aloe vera. Bioorg Med Chem Lett. 2006;16(4):949-53.

11. Tanaka M, Misawa E, Ito Y, Habara N, Nomaguchi K, Yamada M, dkk. Identification of five phytosterols from Aloe vera gel as anti-diabetic compounds. Biol Pharm Bull. 2006;29(7):1418-22.

12. Arkeman H. Healing of goblet cell hyperplasia on mice airway due to cigarette exposure by vitamin $\mathrm{C}$ and $\mathrm{E}$. Buku panduan dan kumpulan abstrak Pertemuan Ilmiah Nasional PAAI, 2007.

13. U.S. Department of Health and Human Services. A report of the surgeon general: how tobacco smoke causes disease: what it means to you. Atlanta: U.S. Department of Health and Human Services, Centers for Disease Control and Prevention, National Center for Chronic Disease Prevention and Health Promotion, Office on Smoking and Health; 2010.

14. Williamson G, Coppens P, Serra-Majem L, Dew T. Review of the efficacy of green tea, isoflavones and aloe vera supplements based on randomised controlled trials. Food Funct. 2011;2(12):753-9.

15. Ni Y, Turner D, Yates KM, Tizard I. Isolation and characterization of structural components of Aloe vera L. leaf pulp. Int Immunopharmacol. 2004;4(14):1745-55.

16. Droemann D, Goldmann T, Tiedje T, Zabel P, Dalhoff K, Schaaf B. Toll-like receptor 2 expression is decreased on alveolar macrophages in cigarette smokers and COPD patients. Respir Res. 2005;6:68.

17. Meier P, Finch A, Evan G. Apoptosis in development. Nature. 2000;407(6805):796801.

18. Zimmermann KC, Green RD. How cells die: apoptosis pathways. J Allergy Clin Immunol. 2001;108(4 Suppl):S99-103.

19. Liu SK, Chen P, Chen JB. Apoptosis of alveolar epithelial cells and pulmonary vascular endothelial cells in chronic obstructive pulmonary disease. Zhonghua 